\title{
Tar Ildikó
}

\section{Memóriatechnikák a szaknyelvoktatásban}

\author{
Ildikó Tar: Memory techniques in language teaching
}

\begin{abstract}
The goal of the present study is to explore the types and development potentials of memory techniques in the group of direct learning strategies, based on Oxford's taxonomy. The actuality of the research topic is underlined by two various background studies on whether students use learning strategies; if yes, what kind. The first study was carried out at the Medical Faculty of Debrecen, while the other one at the Agricultural and Food Sciences one, and the findings were compared. Our results suggest that students use very few strategies, especially hardly any direct ones to learn words. This fact draws our attention to the significance of memory techniques in language learning to make the process easier and more enjoyable.
\end{abstract}

Key words: memory techniques, language learning strategies, direct-indirect strategies, associations, short term - long term memory

\section{ÖSSZEFOGLALÓ}

A tanulmány Oxford taxonómiája alapján a direkt nyelvtanulási stratégiák közé tartozó memóriatechnikák típusait, fejlesztési lehetőségeit vizsgálja. A téma aktualitását a Debreceni Egyetemen folytatott két különböző, a hallgatók tanulási stratégiáira vonatkozó vizsgálat adja, mely arra irányult, használnak-e a hallgatók tanulási stratégiákat, és ha igen, melyeket. Az egyik vizsgálatot a DEOEC hallgatói, a másikat pedig a DE Agrártudományi Karán végeztük, s összevetettük a hallgatók válaszai alapján kapott helyzetképet. Eszerint a hallgatók kifejezetten kevés stratégiát használnak, ső́t a szótanulásra szinte alig használnak direkt stratégiákat. Ezért (is) lehet hasznos a szaknyelvoktatásban a memóriatechnikák használata, mellyel könnyebben, élvezetesebben lehet eredményeket elérni.

Kulcsszavak: memóriatechnikák, nyelvtanulási stratégiák, direkt-indirekt stratégiák, asszociációk, hosszú-rövid távú memória
A 21. században a globalizáció és az ezzel együtt járó mobilitás, munkavállalás stb. a nyelvtanulást minden eddiginél fontosabb követelménnyé tette. A világcégek számára nem annyira a nyelvvizsga bizonyítvány, mint a magabiztos, munkaképes nyelvtudás számít amit gyakran telefonon is tesztelnek, pedig ez sokszor még anyanyelven sem könnyú. Ahogyan Weitz Teréz a memóriatechnikákról írott cikkében említi, az információs forradalom olyan követelményeket állít elénk, amellyel agyunk alig tud megbirkózni. Egymást érik az új és még újabb adathordozók, kommunikációs eszközök: mire ráállunk valamelyik használatára, kezdhetjük elölről a sokszor felhasználó-barátnak egyáltalán nem nevezhető rendszerek és alkalmazások megtanulását. Érdekes folyamat, hogy az okostelefonoktól kezdve a tabletekig szinte mindenhol alapfunkció a naptár, a programtervező, jegyzettömb stb., - mely mind a memóriát igyekszik tehermentesíteni: ezért aztán alig érzünk késztetést, hogy bármit tudatosan memorizáljunk. Így van ez a szavakkal is: sokkal egyszerúbb online szótárakban pillanatok alatt megnézni, fordítási memóriákból ötleteket meríteni, csak egy gond van: ha beszélni 
akarunk, akkor mégis a memóriánk az egyetlen, amire támaszkodhatunk. A szótanulásra, a nyelvtani rendszerek kiépítésére más módszerekkel kell rávennünk tanítványainkat, akik napjaik nagy részét a képernyő előtt töltik, szinte alig olvasnak könyveket, s mindezt úgy, hogy ne a képernyő-zombik amúgy is népes táborát növeljük.

Magyarországon a helyzet még egy tekintetben bonyolult: a „poroszos” szellemú évtizedek hatásaként a diákok sokat hallgatnak -nem véletlenül hívjuk őket „hallgatónak”, és kerülik a kommunikációt, vagy pedig anyanyelvüket használják erőteljes kudarckerülő magatartásként („Nem szólalok meg angolul, mert mi lesz, ha hibázom?"). Ez a kezdeti ellenállás és kudarckerülés általában sokáig tartja magát, s később oldódik a felsőbb évfolyamokon.

Említhetjük továbbá az egyetemi tantermek berendezését, ahol a hatalmi távolság ( $P D=$ power distance) erőteljesen érvényesül, és nem ad lehetőséget „beszélgető" nyelvórák tartására, még akkor sem, ha arra igény mutatkozna.

\section{BEVEZETÉS}

A szaknyelvoktatásban különösképpen nagy szerepe van a szótanulásnak, amit sokszor tovább bonyolít, hogy egy adott szó mást jelent a köznyelvben és mást a szaknyelvben. A szakfordító hallgatók helyzetét még megnehezíti a megtanulandó szavak rendszeres, hatalmas mennyisége. Hallgatóink sokszor panaszkodnak arra, hogy nem bírnak (akarnak, tudnak) magolni, más módszereket pedig nemigen ismernek. Memóriatechnikákat csak elvétve tanítanak az iskolákban, s tapasztalatom szerint még az egyetemi oktatásban sem késő hosszabb vagy rövidebb anyagok megtanulását oktatni, lehetőleg többfélét, hogy mindenki a saját információbeviteli preferenciájának megfelelőt tudjon választani magának. Korábban $(2010,2012)$ két felmérést végeztem a Debreceni Egyetem orvostanhallgatói és a Mezőgazdasági Kar hallgatóinak körében az általuk ismert és használt tanulási stratégiák megismerésére. Bár a két kar hallgatói sok mindenben különböznek, a kérdőív eredményei nagymértékben egyöntetű eredményeket hoztak. Eszerint a DEOEC és a DE AGTC MÉK hallgatói egyaránt nehézségekkel küzdenek, miközben beilleszkedni és sikeresen helytállni igyekszenek az egyetemi környezetben. Különösen kiemelkedik a tanulási stratégiák és memóriatechnikák ismeretének hiánya mindkét hallgatói csoport körében, a lényeg kiemelésének nehézségei olvasás, tanulás közben, a figyelem elkalandozása, valamint a stresszes helyzetek (vizsga, tesztek) nem megfelelő kezelése. Egy konkrét adat: az orvostanhallgatók 70\%-a számára jelent problémát az olvasás, jegyzetelni pedig már nem is nagyon szoktak - sokan nem is tudnak!

Ez, valamint a saját mindennapi munkámban jelentkező tanulás-szótanulás megkönnyítése és eredményesebbé tétele motivált arra, hogy memóriatechnikákat tanítsak minden hallgatónak, aki a csoportjaimba kerül.

\section{MEMÓRIATECHNIKÁK}

A tanulási stratégiák, mint a tudatos tanulói tevékenység megnyilvánulásai, nagyban segítik a nyelvtanulás sikerességét, és használatuk csökkentheti a nyelvtanulás során fellépő szorongás szintjét. A memóriatechnikákat Rebecca Oxford [2003] taxonómiája a tanulók által használt közvetlen tanulási stratégiák közé sorolja. A memóriatechnikák funkciója az információ tárolásának, elóhívásának megkönnyítése, és Oxford szerint ez a következőket foglalja magába: mentális kötések, kapcsolatok kialakítása, képek és hangok rögzítése, az adott információ alapos áttekintése, valamint különböző cselekvések útján történő rögzítése.

\section{A MEMÓRIA}

Eisler Olga Mindennapi memóriánk c. könyve szerint a feledékenység minden embert érint: „részben azért felejtünk, hogy emlékezhessünk arra, ami igazán fontos" [Eisler 2002: 8]. Ezzel szemben, rövid vagy hosszú távú memóriánkat arra próbáljuk rábírni, hogy minden egyes nap 
bennünket szolgáljon... A memorizálás múveletét számos tényező segíti, rengeteg viszont gátolja. A gátló tényezők közül hallgatóinknál a következők fordulnak leggyakrabban elő: a stressz, az érdektelenség, az önvédelemi feledékenység (sokszor nem is tudatos), a memória nem megfelelő karbantartása (bulizás, serkentő szerek, kialvatlanság, stb.). A segítők közül néhány: pozitív érzelmek szerepe (nem utálom azt, amit tanulok, nem győzködöm magam, hogy ez nekem úgysem megy), stressz kezelési módszerek tudatos elsajátítása, relaxációs technikák rendszeres gyakorlása, a tanulási folyamat beosztása, ütemezése, átgondolása (időgazdálkodás), megfelelő (agyserkentő) étrend, a koncentráció tudatos gyakorlása. Érdemes hangsúlyozni ezek mellett még az „időrablók” megfékezését és a halogatás legyőzését - összességében egy céltudatos, határozott, pozitív beállítottságú személyiség kialakításának szükségességét az individuáció Jung által említett folyamatában.

\section{MEMÓRIATECHNIKÁK ÉS NYELV- TANULÁS}

$\mathrm{Az}$ alábbiakban a teljesség igénye nélkül az óráimon leggyakrabban használt memóriatechnikákat mutatom be.

- Asszociáció: A tanulási folyamat során kapcsolatot képzünk formák és gondolati egységek között, értelmet vagy tartalmat adunk annak az új elemnek, amivel találkozunk. Mindezt erősen befolyásolja a történés érzelmi tartalma, mert ha nem pozitív, igyekszünk tőle megszabadulni, és gyorsan elfelejteni. Az asszociáció képessége függ a személyiségtől, az élettapasztalattól, a világ egyéni észlelésétől, az olvasottság szintjétől, az érdeklődéstől stb. A szakfordító hallgatók fordítás közben gyakran találkoznak azzal a problémával, hogy mivel mindenben a technikára hagyatkoznak, memóriájuk nem „pörög” elég gyorsan, amikor szinonimaasszociációkra lenne szükség akár angolul, akár magyarul, hogy csak valóban azokat a szavakat kelljen megnézni, amiket nem ismernek. Szakszövegelemzés c. óránk egy részét az asszociációs folyamat felgyorsítására szánt gyakorlatok teszik ki.

- Gondolati háló: Az "eletkepesangol" weboldal tanácsai szerint a szavak megjegyzését megkönnyíti, ha gondolati és logikai keretbe rendezzük el őket. A bevésést tovább mélyíti, ha mentális képeket, mozgást, ízt és egyéb érzékeket is hozzájuk kapcsolunk, ezzel is növelve a memória-kapacitást. A szavak többszintú és többféle összekapcsolása után a megtanultak sokáig megmaradnak ebben a keretben, és nem esnek ki olyan gyorsan, mint amikor előző este épp csak bemagolják hallgatóink egy adott dolgozatra. A szóhálókat le is lehet rajzolni, ki is lehet színezni, formákba lehet önteni, ill. jelölni lehet az állandó szókapcsolatokat is. Több információ a szóhálókról: http://eletkepesangol.blog.hu/page/4 http://drawingenglish.hu/?p=341 és még több az asszociációkról: http://wordassociations.net.

- A római szoba módszer: a rómaiak által kifejlesztett, meglehetősen jól ismert memóriatechnika, mely segítségével akár több száz, vagy akár több ezer pontból álló listákat is meg lehetett jegyezni. Azok közé a memóriatechnikák közé tartozik, melyeket a lehető legkönnyebb hasznosítani a nyelvtanulásban. Használható szótanulásra, de a nyelvtani struktúrák áttekintésére illetve bevésésére is kiválóan alkalmas. „Vegyük például a saját szobánkat, amit ugyebár nagyon jól ismerünk és a megjegyzendő dolgokat kapcsoljuk úgy össze a szobánkban lévő dolgokkal, hogy közben magunk előtt látjuk a szobát. Azaz vizualizáljuk. Elhelyezhetünk dolgokat az ágyon, a szekrényen, a szőnyeg közepén és így tovább. A szoba lehet természetesen kitalált is, valójában bármilyen helységet használhatunk, ez csak a saját fantáziánktól függ" http://eletkepesangol.blog.hu/page/4.

- Mind map (Pókábra): adott témáról szerzett információkat fúz logikai rendszerbe 
vizuális formában. Kiválóan alkalmas a fóbb egységek és azok alpontjainak felidézésére. Egyéni fantáziánk szab csak határt annak, hogyan alakítjuk az információt hordozó szövegdobozokat (köröket, rombuszokat, négyzeteket, virágokat stb.), ezeket milyen színekkel tesszük még inkább felidézhetővé, és hogy az óramutatóval megegyezően vagy épp ellenkezően haladunk az alegységek mentén. A módszer azért is eredményes, mert saját erőfeszítésünk kell az ábra megalkotásához, s saját logikánk szerint építjük fel, amit a lehető legkönnyebb követnünk.

- Utazás módszer - ez a módszer is különösen jól használható egymást követő egységek illetve alegységek sorrendiségének és az adott elemek számának megjegyzésére. Először a valóságban, majd képzeletben az egymást követő helyiségeihez kapcsoljuk az adott információegységet, amit a stabil gondolati vezérfonal mentén bármikor könnyen fel lehet idézni.

- Hosszabb szöveg (könyv, jegyzet) tanulása: SQ3R módszer - klasszikus módszer, mely a kognitív pszichológia kutatási eredményein alapul és a tananyaggal való aktív, intenzív gyakorlást hangsúlyozza. A módszer neve egy angol mozaikszóból származik: S-survey (átnézés), Q-question (kérdezés), R -read (olvas), $\mathrm{R}$ - recite (felmond) és $\mathrm{R}$-review (ismétlő áttekintés). A Q pontot én a lényeg rövid kiemelésére szoktam módosítani, melyet írásban rögzítek (azaz kijegyzetelem), ezzel lerövidítve a megtanulandó anyagot. [Tánczos 2011: 7]

- Ismétlés: Nyelvtanulás és diszlexia c. könyvében Tánczos (2007:67) azt ajánlja, hogy osszuk fel a tanulásra fordított időt 20-50 perces egységekre, s minden egyes szakasz után tartsunk 10 perc pihenőt, majd pihenjünk és végezzünk valami teljesen más tevékenységet, főleg testmozgást Egy szót kb. 70-szer kell ahhoz ismételnünk (hallanunk, látnunk, stb.), hogy a hosszú távú memóriába bekerüljön! Érdemes az anyagot a következőképpen többször átismételni: 10 perccel a tanulás befejezése után,1 nappal a tanulás befejezése után,1 héttel a tanulás befejezése után, 1 hónappal a tanulás befejezése után, végül 6 hónappal a tanulás befejezése után.

- Recencia elv: Tánczos Judit említi könyvében a recencia vagy újszerüségi hatás múködési elvét is [Tánczos 2007: 65]. Agyunk az új információt részesíti előnyben a régi, megszokottal szemben, ezért érdemes ezt a preferenciát hasznosítani. $\mathrm{Ha}$ pl. egy harminc szavas szólistát olvasnának fel nekünk, majd visszamondatnák velünk az elhangzott szavakat, akkor csak a lista elején és végén lévő szavak közül emlékeznénk viszonylag több szóra, míg a közepéről csak nagyon kevés szót tudnánk felidézni. Ezt a hatást nevezik elsőbbségi és recencia hatásnak. Ha csak nem alkalmaznánk valamilyen mnemotechnikai eljárást, akkor nagy valószínűséggel nem tudnánk az összes szót megjegyezni.

\section{SZÁMÍTÓGÉP: ONLINE TANULÁST SEGÍTŐ OLDALAK A NYELVTANULÓK SZÁMÁRA}

Kőrösi Bálint Öt év-öt nyelv címen internetes blogot vezet, melyben számos, a nyelvtanulásban kiválóan felhasználható forrást említ. Javasol először is egy olyan online tesztet, mely megmutatja, hogy az adott nyelvtanuló milyen típusba tartozik az információ befogadását illetően: vizuális, auditív vagy kinesztetikus:http://www.businessballs.com/va klearningstylestest.htm

A nyelvtanulásban örökzöldnek számító szókártya módszerre az Anki ill. a Memrise nevú tanulást segítő programokat ajánlja, és megemlíti a magyar fejlesztésú learninvisible.com honlapot. Mindhárom azt célozza meg, hogy a rövid távú memóriából a hosszabb távúba tudjuk az ismereteket (szavakat) átvinni. A learninvisible módszer lényege a memória aktivizálása a képek, szavak hiányos bemutatásával: ilyenkor agyunk, mivel az egészről alkotott képet részletekből rakja 
össze, pótolja a hiányzó információt, és ezáltal aktiválódik. Izgalmas módszernek tartja a mnenomika módszert (http://otevotnyelv.com/hatekony_szotanulas/ ), mely a megtanulandó szót történetbe építi be, $s$ ezáltal az könnyebben megmarad a memóriában.

Ide kapcsolódik a Quizlet nevű nyelvtanulást http://quizlet.com/subject/angol-magyar/ segítő internetes portál, amely a create list funkcióval lehetővé teszi, hogy a hallgató a saját szóanyagát bevigye pl. angolul-magyarul, majd ha kész a lista, azokból többféle (hallás, látás, íás alapú) online gyakorlatot gyárt, melyek megoldását azonnal javítja is - ezek elvégzését követően „tanulni” hagyományos értelemben már szinte nem is kell! Hallgatóim visszajelzései szerint nem csak nyelvet, de pl. a növényélettan tantárgyat is kiválóan lehet vele tanulni, azaz száraz adatok pontos, hosszú távú rögzítésére is alkalmas.

\section{EGYÉB ONLINE NYELVTANULÁS MÓDSZEREK}

Világbajnok könyvek a memória fejlesztéséről: gondolatbaejto.blog.hu

Mindtools:

www.mindtools.com/pages/article/newTIM 10 htm - angol nyelvű cikk a nyelvtanulás alapvető és praktikus kérdéseiről, tippekkel

Mindsnacks: $\quad$ www.mindsnacks.com memóriafejlesztő játékok portálja

lyricstraining.com: zeneszámok szövegeit kell kiegészíteni

fluentu.com - a YouTube videókból keresi ki az éppen tanult szavakat, ezáltal valódi szövegkörnyezetben lehet azokat megtanulni

lang-8.com - anyanyelvű beszélők javítják a tanuló kiejtését

hemingwayapp.com: az angol nyelvú fogalmazásban seg

5perc Angol - igen elterjedt és népszerú fejlesztő program, magazin formában is elérhetó angolnyelvtanitas.hu - anyagok, ötletek, nyelvvizsgák, tippek

www.newsinlevels.com - különböző szintú angol cikkek az eredeti nyelven híreket olvasni vágyóknak

www.fluentizer.com - ingyenesen letölthető hangoskönyv-felolvasóként működik, tetszőleges nyelvpár beállítását engedélyezi, s a hallgató által nem értett (megjelölt szavakat) lefordítja, majd többféle kiejtéssel kimondja.

\section{ÖSSZEGZÉS}

Hallgatóinknál a tanulási stratégiák minimális használata súlyos hiányosságra hívja fel a figyelmet: e tanulássegítő direkt és indirekt módszereket érdemes bármely tanóra keretében megismertetni velük. A stratégiák rendszerén belül a memóriatechnikák oktatása igényként fogalmazódik meg nem csak a nyelvtanulókban, hanem az ,átlag” diákban is, a szaknyelvoktatásban pedig szinte kihagyhatatlan.

A 21. század nyelvtanításának nap mint nap alkalmazkodnia kell a technológiai forradalom rohanó üteméhez, a folyamatosan megújuló és piacra dobott elektronikus eszközökhöz, új szoftverekhez. Mindezt úgy, hogy egyfajta iránymutatást is nyújtson: ezek az eszközök nagyon hasznosak lehetnek, ha megfelelö célokra és nem csak játékra vagy beszélgetésre alkalmazzuk őket. Memóriánknak ugyanakkor fejlesztésre van szüksége ahhoz, hogy pl. idegen nyelven társalogva folyamatosan beszélni lehessen, ezért fontos a megfelelő egyensúly kialakítása a gépek nyújtotta kényelem és a hosszú-rövid távú memória edzése között.

A szótanulás megkönnyítése, a szavak bevésése pl. kiválóan megkönnyíthető direkt erre a célra kifejlesztett programokkal, melyeket akár napközben, utazás közben stb. is lehet használni. Segítségükkel olyan nyelvtudás birtokába juthatunk, mintha anyanyelvi környezetben élnénk-dolgoznánk - csak épp a számítógép, tablet, okostelefon segítségével, akár otthonról. 


\section{BIBLIOGRÁFIA}

[1] Eisler O. (2002): Mindennapi memóriánk. Budapest: Saxum Kiadó.

[2] Tánczos J. (2007): Nyelvtanulás és diszlexia. Módszerek a tanulási zavarral küszködő tanulók idegennyelv oktatásához. Debrecen: Pedellus Tankönyvkiadó.

[3] Tánczos J. (2011): Eredményes tanulási technikák (PD-327) Debrecen: Pedellus Tankönyvkiadó.

\section{FORRÁSOK}

[4] Öt év, öt nyelv. Hatékony és szórakoztató nyelvtanulás. http://otevotnyelv.com/hatekony szotanulas

[5] Businessballs, free personal and organisational resources, materials, teplates, samples, examples, tips and tools. http://www.businessballs.com/vaklearningstylestest.htm.

[6] Language learning app: learninvisible.com 